Article

\title{
Antibiotic Resistance and Genotypes of Helicobacter pylori Strains in Patients with Gastroduodenal Disease in Southeast Poland
}

\author{
Izabela Korona-Glowniak ${ }^{1, *}$, , Halina Cichoz-Lach ${ }^{2}$, Radoslaw Siwiec ${ }^{1}$, Sylwia Andrzejczuk ${ }^{1}$, \\ Andrzej Glowniak ${ }^{3}{ }^{\circledR}$, Przemyslaw Matras ${ }^{4}$ and Anna Malm ${ }^{1}$ \\ 1 Department of Pharmaceutical Microbiology with Laboratory for Microbiological Diagnostics, \\ Medical University of Lublin, Chodzki Str. 1, 20-093 Lublin, Poland \\ 2 Department of Gastroenterology with Endoscopic Unit, Medical University of Lublin, Jaczewskiego Str. 8, \\ 20-090 Lublin, Poland \\ 3 Department of Cardiology, Medical University of Lublin, 20-090 Lublin, Jaczewskiego Str. 8, \\ 20-090 Lublin, Poland \\ 4 Chair and Department of General and Transplant Surgery and Nutritional Treatment, \\ Medical University of Lublin, Jaczewskiego Str. 8, 20-090 Lublin, Poland \\ * Correspondence: iza.glowniak@umlub.pl; Tel.: +48-814-487-100
}

Received: 13 June 2019; Accepted: 18 July 2019; Published: 21 July 2019

check for updates

\begin{abstract}
The aim of this study was to investigate genetic diversity of Helicobacter pylori virulence markers to predict clinical outcome as well as to determine an antibiotic susceptibility of $H$. pylori strains in Poland. Gastric biopsies from 132 patients with gastrointestinal disorders were tested for presence of $H$. pylori with the use of rapid urease test, microbial culture, and polymerase chain reaction (PCR) detection. The genetic diversity of $62 \mathrm{H}$. pylori positive samples was evaluated by detection of $c a g A$ and PCR-typing of $v a c A$ and ice $A$ virulence-associated genes. Most common H. pylori genotypes were cag $A(+) v a c A s 1 m 2$ (27.4\%) and cag $A(-) v a c A s 2 m 2$ (24.2\%). In logistic regression analysis, we recognized the subsequent significant associations: gastritis with ureC, i.e., $H$. pylori infection $(p=0.006)$, BMI index $(p=0.032)$; and negatively with iceA1 $(p=0.049)$ and peptic ulcer with $\operatorname{cag} A$ ( $p=0.018)$. Thirty-five H. pylori strains were cultured and tested by E-test method showing that $49 \%$ of strains were resistant to at least one of the tested antibiotics. This is the first study that reports the high incidence and diversity of allelic combination of virulence genes in gastroduodenitis patients in Poland. Genotyping of $H$. pylori strains confirmed the involvement of cagA gene and vacAs $1 m 1$ genotype in development and severity of gastric disorder.
\end{abstract}

Keywords: pylorus infection; $\operatorname{cag} A$; vacA; ice $A$; antibiotic patterns

\section{Introduction}

Helicobacter pylori is an etiological factor of the most frequent and persistent bacterial infection worldwide, which affects nearly half of the world's population. H. pylori infections are more common in developing countries-up to $90 \%$ of population, whereas in developed countries-below $40 \%$ [1]. In northern Europe, about 30\% of adults are infected, whereas in south and east Europe the prevalence of $H$. pylori is often higher than $50 \%$. The highest prevalence was reported in Portugal, similarly to Poland, where $84 \%$ of adult population is infected with this bacteria, which is a serious epidemiological problem $[2,3]$. H. pylori is associated with gastric ulcer, peptic ulcer disease, gastric cancer, and mucosa-associated lymphoma, but about $70 \%$ of infected population are carriers who stay asymptomatic [4]. 
The clinical outcome of $H$. pylori infection was supposed to be linked to certain strains differing in virulence factors presence or subtypes [5]. The presence of the cytotoxin-associated gene A $(\operatorname{cag} A)$ and the most active (s1m1) form of the vacuolating toxin (vacA) are the most important features of the bacterium in relation with higher risk of gastric adenocarcinoma and its pre-malignant lesions [6-9]. H. pylori is genetically heterogeneous, suggesting a lack of its clonality. It results in every H. pylori-positive subject carrying a distinct strain. This is possibly an adaptation of H. pylori to the gastric conditions of its host, as well as to the distinct patterns of the host-mediated immune response to $H$. pylori infection [10].

Treatment failure of $H$. pylori infection is caused mainly by progressive antibiotic resistance among $H$. pylori strains and numerous studies have shown that the prevalence of $H$. pylori antibiotic resistance varies significantly between countries, and even between regions within the same country. Local surveillance of antibiotic resistance is warranted to guide clinicians in their choice of therapy [11]. In regions with low resistance rates to clarithromycin (less than 20\%), a standard first line-therapy which contains clarithromycin is recommended. In regions with high resistance to clarithromycin $(>20 \%)$, first-line therapy with bismuth salts is recommended and, if it is not available, sequential therapy (Proton Pump Inhibitor (PPI), amoxicillin for 5 days and PPI, clarithromycin, metronidazole, or tinidazole for the next 5 days) [3,12].

Numerous diagnostic assays for H. pylori detection are available: bacterial culture, a rapid urease test (RUT), a urea breath test, histology, polymerase chain reaction (PCR), serology, and stool antigen test [13]. All these techniques have their limitations. Here we have tried to compare three diagnostic methods-microbiological culture, rapid urease test (RUT), and detection of ureC gene by PCR in biopsies from patients with gastroduodenal disease. Moreover, the pathogenicity of $H$. pylori strains was evaluated by detection of cytotoxin associated gene A $(c a g A)$, and genotyping of vacuolating cytotoxin gene $\mathrm{A}(\mathrm{vac} A)$ and iceA gene and correlated them with the clinical outcomes. Antibiotic resistance was assessed by $H$. pylori culture and antibiotic susceptibility testing to monitor effectiveness of recommended treatments.

\section{Material and Methods}

\subsection{Patients}

Gastric biopsies were collected from 132 patients with indication of endoscopy (78 women and 54 men, the mean age 57.3 years, SD 15.6, median 59 years, range 20-87 years) who attended the Department and Clinic of Gastroenterology with Endoscopic Unit of Medical University of Lublin, Poland in 2016. Gastric biopsies were evaluated according to updated Sydney System. Chronic gastritis was defined as increased number of lymphocytes and plasma cells in the lamina propria of gastric mucosa. The degree of inflammation was referred to as mild, moderate and severe. Activity of inflammation was determined on the basis of neutrophilic infiltrates of the lamina propria, pits, or surface epithelium. Mild activity was diagnosed when less than one third of pits and surface was infiltrated, moderate- one-third to two-thirds, more than two-thirds defined severe activity of gastritis. The presence of atrophy, intestinal metaplasia, and intraepithelial neoplasia were determined. Attention was paid to the presence of lymphoplasia and erosions. In 23 male and in 21 female patients, moderate chronic gastritis with moderate activity was diagnosed, 2 remaining women had severe chronic gastritis with moderate activity. In two men, intestinal metaplasia was diagnosed and in none of the patients atrophic gastritis was confirmed. The participants with unintentional weight loss within the previous 6 months, upper abdominal mass, dysphagia, previous gastric resection, bleeding tendency and pregnancy were excluded from the study. Two biopsies from the distal corpus and two biopsies from the antrum were obtained during the panendoscopy. The endoscopic examination findings were: gastritis/duodenitis, peptic ulcer (gastric or duodenal ulcer), GERD (gastroesophageal reflux disease), and normal (Table 1). From each patient, informed consent was obtained. The Ethical Committee of the Medical University of Lublin approved the study protocol (no. KE-0254/174/2014). 
Table 1. Demographic and clinical features of studied population.

\begin{tabular}{cccc}
\hline & \multicolumn{3}{c}{ No. of Patients (Mean Age in Years \pm SD) } \\
\cline { 2 - 4 } Clinical Diagnosis & $\begin{array}{c}\text { Male } \\
(\boldsymbol{n}=\mathbf{5 4})\end{array}$ & $\begin{array}{c}\text { Female } \\
(\boldsymbol{n}=\mathbf{7 8 )}\end{array}$ & $\begin{array}{c}\text { Total } \\
(\boldsymbol{n}=\mathbf{1 3 2})\end{array}$ \\
\hline Gastritis/duodenitis & $23(57.0 \pm 15.3)$ & $23(57.5 \pm 16.6)$ & $46(57.2 \pm 15.6)$ \\
Peptic ulcer (gastric/duodenal) & $4(55.0 \pm 12.6)$ & $5(66.4 \pm 10.6)$ & $9(61.3 \pm 12.3)$ \\
Gastroesophageal reflux disease & $27(58.1 \pm 15.5)$ & $44(56.2 \pm 16.4)$ & $71(56.9 \pm 16.0)$ \\
Normal & $1(31.0)$ & $5(57.4 \pm 17.6)$ & $6(53.0 \pm 19.1)$ \\
\hline
\end{tabular}

\subsection{Culture, Identification, and DNA Extraction}

Samples were tested for the presence of urease with the use of RUT-Rapid Urease Test (CLO test Kimberly-Clark) and placed in tubes with $0.9 \% \mathrm{NaCl}$ solution and transported to the Department of Pharmaceutical Microbiology with Laboratory for Microbiological Diagnostics, Medical University of Lublin, Poland. Biopsies were smashed with the use of two microscope slides and spread onto Schaedler agar (BioMerieux, Marcy-l'Étoile, France) with 5\% sheep blood plates and Schaedler agar with $5 \%$ sheep blood plates additionally supplemented with DENT (Oxoid), incubated for 3-7 days at $35{ }^{\circ} \mathrm{C}$ in microaerophilic (5-10\% $\mathrm{CO}_{2}, 80-90 \% \mathrm{~N}_{2}, 5-10 \% \mathrm{O}_{2}$, Generbag microaer, BioMerieux) conditions. H. pylori isolates were identified by colony morphology, Gram-staining and positive catalase $\left(3 \% \mathrm{H}_{2} \mathrm{O}_{2}\right)$, urease and oxidase (BBL DrySlide Oxidase-Becton Dickinson, Franklin Lakes, NJ, USA) tests.

DNA of biopsy sample and bacterial isolates were extracted using QIAGEN QIAamp DNA Mini Kit (Qiagen, USA) according to the manufacturer's instructions. The identification in biopsy samples and isolates were further confirmed as $\mathrm{H}$. pylori using ure $\mathrm{C}$ gene amplification with specific primers [14]. Extracted DNA was frozen to $-70^{\circ} \mathrm{C}$ until its use.

\subsection{Amplification Experiments and Gene Detection}

Determination of the presence $c a g A$ and genotypes of the genes $v a c A s, v a c A m$, ice $A$ was performed by PCR amplification of the target genes from genomic DNA, using previously described oligonucleotides and protocols $[15,16]$. PCR reactions were performed with the use of the REDTaq ReadyMix PCR Reaction Mix (Sigma-Aldrich, St. Louis, MO, USA), followed by electrophoresis in $1.5 \%$ agarose gel (Sigma-Aldrich, St. Louis, MO, USA).

\subsection{Antibiotic Susceptibility Testing}

The strains obtained during the 72-h cultivation were then suspended in the brain heart infusion broth (BHI, Becton Dickinson, Germany). Cell concentration was determined using a densitometer (BioMeriux). Bacterial suspensions with a density of three according to the McFarland scale, i.e., $10^{8}$ cells $(\mathrm{CFU}) / 1 \mathrm{~mL}$ were used for susceptibility testing. In subsequent steps, the susceptibility of the strains to the antibiotics amoxicillin $(\mathrm{AC})$, clarithromycin $(\mathrm{CH})$, metronidazole $(\mathrm{MZ})$, tetracycline (TC), levofloxacin (LE), and rifampicin (RI) was determined by the E-test method using E-test strips (AB Biodisc, Solna). The strips were placed on Mueller-Hinton agar supplemented with $5 \%$ horse blood and $20 \mathrm{mg} / \mathrm{L} \beta-\mathrm{NAD}$. The incubation was performed in microaerophilic conditions for 3 days in $35{ }^{\circ} \mathrm{C}$. Resistance breakpoints of $H$. pylori were interpreted according to EUCAST (AC- $0.125 \mathrm{mg} / \mathrm{L}$; $\mathrm{CL} — 0.5 \mathrm{mg} / \mathrm{L} ; \mathrm{TC}-1 \mathrm{mg} / \mathrm{L} ; \mathrm{MZ}-8 \mathrm{mg} / \mathrm{L} ; \mathrm{RI}-1 \mathrm{mg} / \mathrm{L} ; \mathrm{LE}-1 \mathrm{mg} / \mathrm{L})$.

\subsection{Statistical Analysis}

Data processing and analysis were performed using STATISTICA 13 (StatSoft. Inc., Tulsa, OK, USA). Shapiro-Wilk test was applied to test normal distribution of continuous variables. The Student $t$-test or Mann-Whitney U-test or Kruskal-Wallis ANOVA analysis for independent variables were used as intergroup comparisons component. The distribution of discrete variables in groups were 
compared with Pearson's Chi-square test or the Fisher's exact test. Odds ratio (OR) and their 95\% confidence intervals (CI) were calculated. Logistic regression models were fitted to identify risk factors associated with different clinical diagnoses (GAST, GERD, PUD) using H. pylori genotypes and demographic data (age, gender, BMI, place of residence, smoking) as independent factors. Statistical significance was set at $p<0.05$. The following indexes were calculated for RUT samples and microbial culture in relation to PCR samples: sensitivity, specificity, positive predictive value (PPV), and negative predictive value (NPV).

\section{Results}

Out of 132 patients, 35 (26.5\%) microbial cultures, 45 (34.1\%) RUT and 62 (47.0\%) PCR tests were positive for $H$. pylori. Significantly higher detection rates for PCR method comparing to microbial culture (RR 3.6, 95\%CI 2.6-4.95, $p<0.0001$ ) and RUT (RR 11.6, 95\%CI 3.8-34.7, $p<0.0001$ ) were observed (Figure 1). Sensitivity of microbial culture in comparison to PCR identification was $56.5 \%$ and specificity $1.0 \%$ (PPV 100.0\% and NPV 72.2\%). RUT test sensitivity was $67.7 \%$ and specificity-95.7\% (PPV 93.3\% and NPV 77.0\%). However, the same analysis carried out in different clinical outcomes showed significant difference in GAST and GERD groups only (Figure 1).

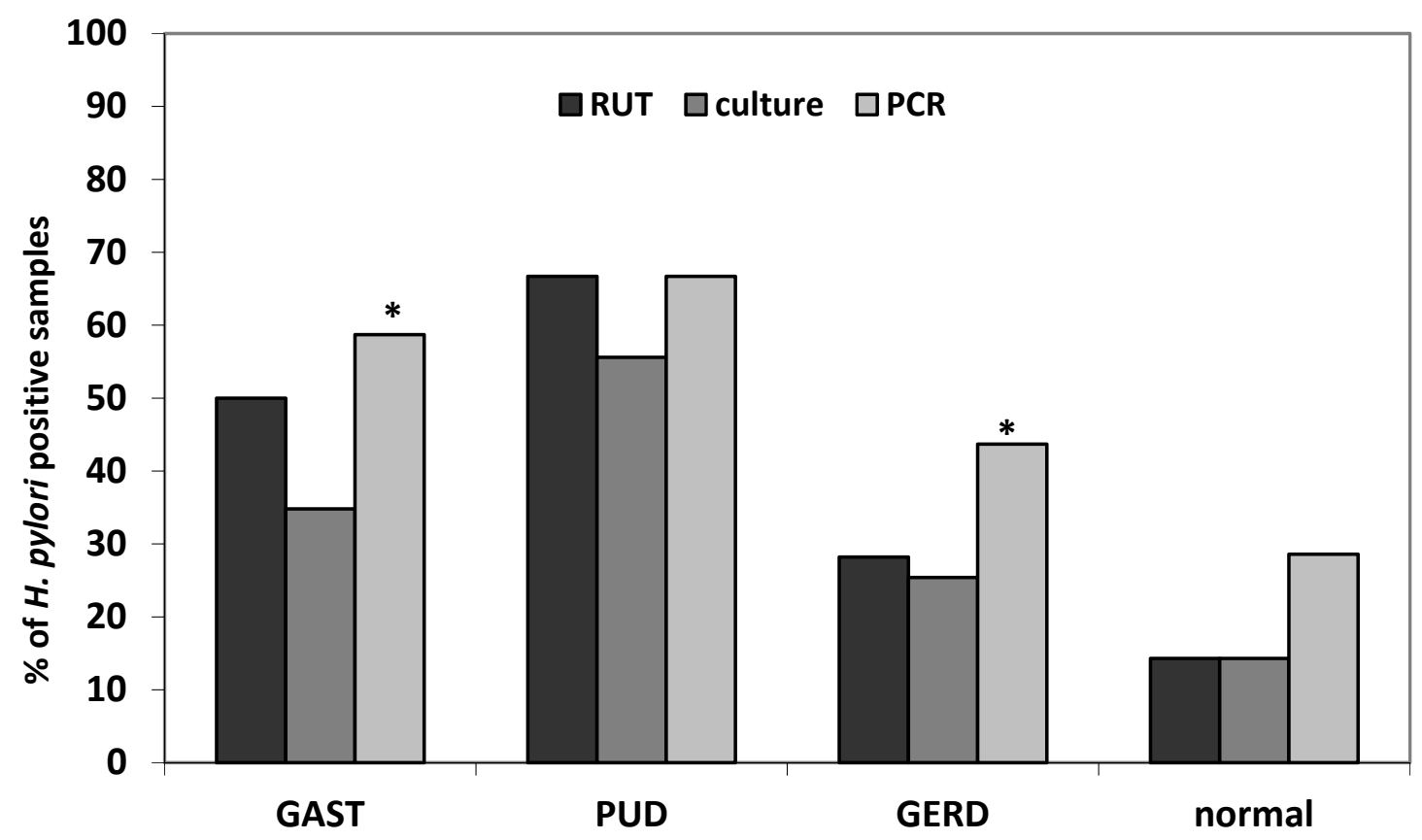

Figure 1. H. pylori identification using different methods regarding clinical diagnosis (GAST, gastritis/ duodenitis; PUD, peptic ulcer disease (gastric/duodenal); GERD, gastroesophageal reflux disease); ${ }^{*} p<0.05$ (PCR vs. culture).

Table 1 presents demographic and clinical features of studied population. Male gender $(57.4 \%$ vs. $39.7 \%$; RR 1.4, 95\%CI 1.0-2.0, $p=0.046)$ and residence in rural areas $(66.0 \%$ vs. $36.9 \%$; RR 1.5 , $95 \%$ CI 1.2-2.0, $p=0.0019$ ) were significantly associated with $H$. pylori infection.

Genotype distribution of $H$. pylori positive samples according to PCR analysis was presented in Table 2. It was shown that $56.5 \%$ of tested $H$. pylori were cagA positive. Regarding iceA gene: distribution of iceA1 and ice $A 2$ were comparable ( $32.3 \%$ and $35.5 \%$, respectively), and in $4.8 \%$ of samples mixed alleles ice $A 1+i c e A 2$ were detected. The vacA s $1 \mathrm{~m} 2$ genotype was the most common in $H$. pylori positive patients, with $33.9 \%$, followed by $s 2 m 2$ with $29.0 \%$ and $s 1 m 1$ with $19.4 \%$. The co-infection of $s 1 m 1$ with $s 1 m 2$ and $s 2 m 1$ with $s 2 m 2$ was observed in $8 \%$ of $H$. pylori positive patients. All but two of the vacA s1 alleles were $s 1 a$ subtype (two strains had $s 1 b$ subtype). None of vacA $m$ alleles were detected in $4.8 \%$ of samples (s1m0). 
Table 2. Distribution of $H$. pylori vacA genes/alleles according to $\operatorname{cag} A$ and $i c e A$ status.

\begin{tabular}{|c|c|c|c|c|c|c|c|}
\hline \multirow{2}{*}{$\begin{array}{c}\text { VacA } \\
\text { Alleles }\end{array}$} & \multicolumn{2}{|c|}{ CagA Status (\%) } & \multicolumn{4}{|c|}{ IceA Genotype (\%) } & \multirow{2}{*}{ Total (\%) } \\
\hline & $\operatorname{CagA(+)}$ & CagA(-) & IceA1 & IceA2 & IceA1+2 & Negative & \\
\hline$s 1 m 1$ & $11(17.7)$ & $1(1.6)$ & $4(6.5)$ & $5(8.1)$ & 0 & $3(4.8)$ & $12(19.4)$ \\
\hline$s 1 b m 2$ & 1 (1.6) & 0 & 0 & 0 & $1(1.6)$ & 0 & 1 (1.6) \\
\hline$s 1 m 1 / s 1 m 2$ & $1(1.6)$ & $2(3.2)$ & 0 & $2(3.2)$ & $1(1.6)$ & 0 & $3(4.8)$ \\
\hline$s 1 m 2$ & $16(25.8)$ & $5(8.1)$ & $10(16.1)$ & 7 (11.3) & 0 & $4(6.5)$ & $21(33.9)$ \\
\hline$s 2 m 2$ & $3(4.8)$ & $15(24.2)$ & $5(8.1)$ & $5(8.1)$ & 0 & 8 (12.9) & $18(29.0)$ \\
\hline$s 2 m 1 / s 2 m 2$ & 0 & $2(3.2)$ & 0 & $1(1.6)$ & 0 & $1(1.6)$ & $2(3.2)$ \\
\hline$s 2 m 1$ & 0 & $1(1.6)$ & 0 & $1(1.6)$ & 0 & 0 & 1 (1.6) \\
\hline negative & 1 (1.6) & 0 & 0 & 0 & 0 & 1 (1.6) & $1(1.6)$ \\
\hline Total & $35(56.5)$ & $27(43.5)$ & $20(32.3)$ & $22(35.5)$ & $3(4.8)$ & $17(27.4)$ & $62(100)$ \\
\hline
\end{tabular}

The most common $H$. pylori genotype infecting studied patients were $\operatorname{cag} A(+)$ vacA s1m2 (27.4\%), $\operatorname{cag} A(-)$ vacA s $2 m 2$ (24.2\%) and $\operatorname{cag} A(+)$ vacA s1m1 (19.4\%). The prevalence of $c a g A$ gene as well as vacA and ice $A$ genotypes varied in clinical outcome, yet without statistical significance (Table 3 ).

Table 3. Genotypes of H. pylori strains and clinical outcome.

\begin{tabular}{|c|c|c|c|c|}
\hline Genotype & $\begin{array}{c}\text { GAST }^{1}(\%) \\
n=27\end{array}$ & $\begin{array}{c}\text { PUD }^{2}(\%) \\
n=6\end{array}$ & $\begin{array}{c}\text { GERD }^{3}(\%) \\
n=31\end{array}$ & $p$-Value \\
\hline \multicolumn{5}{|l|}{ Vac1 genotypes ${ }^{4}$} \\
\hline s $1 m 1$ & $7(25.9)$ & $3(50)$ & $4(12.9)$ & 0.11 \\
\hline$s 1 m 1 / s 1 m 2$ & $2(7.4)$ & 0 & $1(3.2)$ & 0.64 \\
\hline$s 1 m 2$ & $9(33.3)$ & $3(50)$ & $11(35.5)$ & 0.74 \\
\hline$s 2 m 2$ & $7(25.9)$ & 0 & $11(35.5)$ & 0.2 \\
\hline$s 2 m 1 / s 2 m 2$ & $2(7.4)$ & 0 & $1(3.2)$ & 0.64 \\
\hline$s 2 m 1$ & 0 & 0 & $1(3.2)$ & - \\
\hline negative & $1(3.7)$ & 0 & 0 & - \\
\hline \multicolumn{5}{|l|}{$\operatorname{cag} A$ status } \\
\hline positive & $16(59.3)$ & 5 (83.3) & $16(51.6)$ & 0.35 \\
\hline negative & $11(40.7)$ & $1(16.7)$ & $15(48.4)$ & \\
\hline \multicolumn{5}{|l|}{ ice $A$ alleles } \\
\hline$i c e A 1$ & $6(22.2)$ & $3(50)$ & $14(45.2)$ & 0.14 \\
\hline iceA2 & $10(37.0)$ & $3(50)$ & $8(35.8)$ & 0.42 \\
\hline$i c e A 1+2$ & $1(3.7)$ & 0 & $2(6.5)$ & 0.75 \\
\hline negative & $10(37.0)$ & 0 & $7(22.6)$ & 0.14 \\
\hline vacA s1m1/cagA+ & $7(25.9)$ & $3(50.0)$ & $4(12.9)$ & 0.11 \\
\hline vacAs1m2/cagA+ & $6(22.2)$ & $2(33.3)$ & $9(29.0)$ & 0.78 \\
\hline vacAs $2 \mathrm{~m} 2 / \mathrm{cag} A+$ & $1(3.7)$ & 0 & $2(6.5)$ & 0.75 \\
\hline vacAs1m1/cagA- & $1(3.7)$ & 0 & $1(3.2)$ & 0.89 \\
\hline vacAs1m2/cagA- & $4(14.8)$ & 1 (16.7) & $2(6.5)$ & 0.53 \\
\hline vacAs $2 m 2 / c a g A-$ & $6(22.2)$ & 0 & $10(32.3)$ & 0.23 \\
\hline
\end{tabular}

${ }^{1}$ GAST—gastritis/duodenitis; ${ }^{2}$ PUD—peptic ulcer disease (gastric/duodenal); ${ }^{3}$ GERD—gastroesophageal reflux disease; ${ }^{4}$ untyped $\mathrm{m}$-region was found in three samples (s1m0).

In univariate analysis, it was shown that $v a c A s 1 m 1$ was significantly more frequent in patients with gastritis and peptic ulcer (Table A1). However, in logistic regression analysis including epidemiological factors as potential confounders, we recognized the subsequent significant associations: gastritis with ureC presence, meaning $H$. pylori infection (OR 3.3, 95\%CI 1.4-7.9, $p=0.006$ ), BMI index (OR $1.13,95 \% \mathrm{CI} 1.0-1.3, p=0.032$ ), and negatively with iceA1 presence (OR $0.3,95 \% \mathrm{CI} 0.1-1.0, p=0.049$ ); peptic ulcer with $\operatorname{cag} A$ presence (OR 7.7, 95\%CI 1.4-41.6, $p=0.018$ ) whereas GERD with iceA1 (OR 4.5, 95\%CI 1.4-15.2, $p=0.014$ ) and negatively with cagA (OR 0.32, 95\%CI 0.1-0.9, $p=0.025$ ). 
Bacterial cultures were successfully isolated in 35 patients. MIC values of examined $H$. pylori strains showed that all of them were susceptible to amoxicillin and tetracycline (Table 4). Among all strains, $51 \%$ were susceptible to all and $49 \%$ were resistant to at least one of the tested antibiotics. Resistance to clarithromycin, metronidazole, levofloxacin, and rifampicin was found in $5(14.3 \%)$, $11(31.4 \%), 4(11.4 \%)$, and $9(25.7 \%)$, respectively.

Table 4. Susceptibility and MIC values for 35 isolated H. pylori strains.

\begin{tabular}{ccccc}
\hline Antibiotics & Susceptibility (\%) & MIC Range & MIC $_{\mathbf{5 0}}$ & MIC $_{\mathbf{9 0}}$ \\
\hline Amoxicillin & $35(100)$ & $<0.016$ & $<0.016$ & $<0.016$ \\
Clarithromycin & $30(85.7)$ & $<0.016->256$ & $<0.016$ & 16 \\
Metronidazole & $24(68.6)$ & $<0.016->256$ & 0.064 & $>256$ \\
Tetracycline & $35(100)$ & $<0.016-0.19$ & $<0.016$ & 0.094 \\
Levofloxacin & $31(88.6)$ & $<0.002->32$ & 0.047 & 8 \\
Rifampicin & $26(74.3)$ & $<0.002->256$ & 0.5 & 2 \\
\hline
\end{tabular}

MIC, Minimal Inhibitory Concentration; $\mathrm{MIC}_{50}, \mathrm{MIC}_{90}$, lowest concentration of antibiotic at which 50 and $90 \%$ of the isolates were inhibited.

Even though there was a slight difference in amount of resistant strains isolated from patients from different age group, showing their higher frequency in the oldest group, statistical analysis revealed no significant differences $(p=0.13)$ in distribution of resistance patterns between age groups (Figure 2$)$.

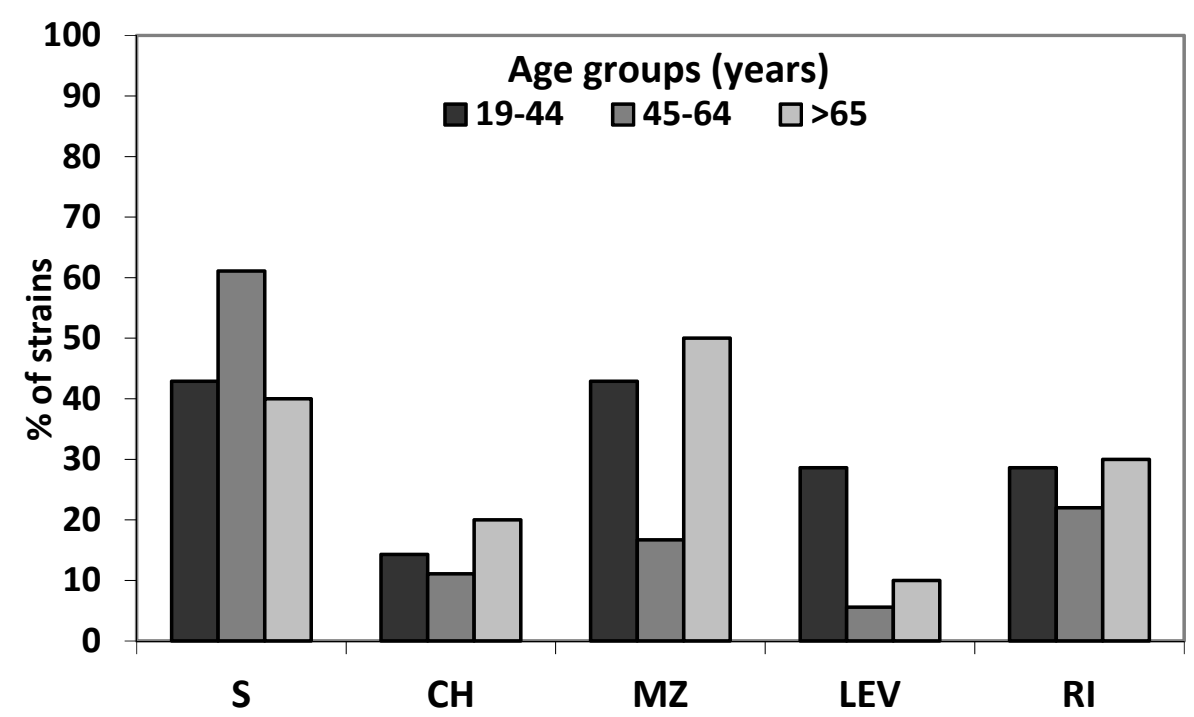

Figure 2. Resistance to tested antibiotics of 35 isolates $H$. pylori strains in different age groups (S-sensitive to all tested antibiotics; $\mathrm{CH}$-clarithromycin; $\mathrm{MZ}$-metronidazole; RI-rifampicin; LEV-levofloxacin).

The multidrug resistant strains (for two or more antibiotics) were observed in eight strains (22.9\%). They were resistant to metronidazole and clarithromycin (50\%) and/or levofloxacin (50\%) and/or rifampicin (50\%) (Table 5). Most of metronidazole resistant strains were found with high MIC value. 
Table 5. Characteristics of multidrug resistant $H$. pylori strains.

\begin{tabular}{|c|c|c|c|c|c|c|c|c|c|c|}
\hline \multirow{2}{*}{ Age } & \multirow{2}{*}{ Gender } & \multirow{2}{*}{ Diagnosis } & \multirow{2}{*}{ Genotype } & \multirow{2}{*}{$\begin{array}{c}\text { Resistance } \\
\text { Pattern }\end{array}$} & \multicolumn{6}{|c|}{ MIC (mg/L) } \\
\hline & & & & & $\mathrm{AC}^{4}$ & $\mathrm{CH}^{5}$ & $\mathrm{MZ}^{6}$ & $\mathrm{LE}^{7}$ & RI $^{8}$ & $\mathrm{TC}^{9}$ \\
\hline 53 & M & GERD $^{1}$ & $\operatorname{cag} A(+) s 1 m 1$ ice $A 2$ & $\mathrm{CH}+\mathrm{MZ}+\mathrm{LE}$ & $<0.016$ & 12 & 24 & $>32$ & 0.125 & 0.19 \\
\hline 64 & $\mathrm{~F}$ & GAST $^{2}$ & $\operatorname{cag} A(+) s 1 m 1$ ice $A 2$ & $\mathrm{CH}+\mathrm{MZ}$ & $<0.016$ & $>256$ & $>256$ & 0.047 & 0.75 & $<0.016$ \\
\hline 70 & $\mathrm{~F}$ & GERD & $\operatorname{cag} A(-) s 2 m 2$ ice $A 2$ & $\mathrm{CH}+\mathrm{MZ}+\mathrm{LE}+\mathrm{RI}$ & $<0.016$ & 8 & 64 & 8 & 2 & $<0.016$ \\
\hline 71 & $\mathrm{~F}$ & GERD & $\operatorname{cag} A(+) s 1 m 2$ ice $A 1$ & $\mathrm{MZ}+\mathrm{RI}$ & $<0.016$ & $<0.016$ & $>256$ & 0.023 & $>256$ & $<0.016$ \\
\hline 44 & M & PUD $^{3}$ & $\operatorname{cag} A(+) s 1 m 2$ ice $A 1$ & $\mathrm{MZ}+\mathrm{RI}$ & $<0.016$ & $<0.016$ & $>256$ & 0.125 & 2 & $<0.016$ \\
\hline 34 & $\mathrm{~F}$ & GERD & $\operatorname{cag} A(+) s 2 m 2 i c e A 1$ & $\mathrm{MZ}+\mathrm{LE}$ & $<0.016$ & $<0.016$ & $>256$ & $>32$ & $<0.002$ & $<0.016$ \\
\hline 29 & $\mathrm{~F}$ & GERD & $\operatorname{cag} A(+) s 1 m 2$ ice $A 2$ & $\mathrm{CH}+\mathrm{MZ}+\mathrm{LE}$ & $<0.016$ & $>256$ & $>256$ & $>32$ & 0.5 & 0.094 \\
\hline 73 & $\mathrm{~F}$ & GAST & $\operatorname{cag} A(-) s 2 m 2$ ice $A 2$ & MZ+RI & $<0.016$ & $<0.016$ & $>256$ & 0.047 & 2 & 0.19 \\
\hline
\end{tabular}

\section{Discussion}

There are several diagnostic assays for $H$. pylori infection, including bacterial culture, a rapid urease test (RUT), a urea breath test (UBT), histology, PCR, serology, and stool antigen test $[10,11]$. All these techniques have their limitations. The sensitivity of isolation of the bacterium has been reported to vary greatly among laboratories because of their fastidious nature [13]. Even the experienced laboratories recover the organism from only $50 \%$ to $70 \%$ of infected biopsies $[17,18]$. In this study, the low positivity rate of the culture (26.5\%) may be due to a low number of bacterial cells, presence of non-culturable coccoid forms, contamination by other bacteria suppressing the growth of $H$. pylori or antibiotic therapy. Moreover, to avoid false negative results, it is recommended for patients not to consume the proton pump inhibitors (PPIs) two weeks before endoscopy, because these drugs indirectly interfere with H. pylori distribution in the stomach [19]. In our study, PCR was the most sensitive and specific method for detection of $H$. pylori. As the bacterial DNA was recovered from $56.5 \%$ of biopsies we consider this method as a reference. Advantages of PCR method are that it detects H. pylori in both forms i.e., spiral or coccoid forms that cannot be detected by other conventional methods [20], is able to discriminate the re-infection or recrudescence by genotyping of infective strains, enables to target pathogenic genes and assess the virulence potential of $H$. pylori in particular patient and does not require strict transport conditions. Therefore, PCR based methods are best for the specimens collected by invasive methods if the tests are carried out without contaminations. Nested PCR was proposed as a gold standard of H. pylori detection [13].

H. pylori infected patients develop superficial gastritis but the course of disease is partly due to environmental conditions and genetics of the host, but also due to the presence of particular virulence factors presented in the infecting H. pylori strains [21]. In this study, we focused on research of population and epidemiology of $H$. pylori, which provide us an information about genotypes linking them with clinical diagnosis. To our knowledge, this study presents the largest characteristic to date of H. pylori isolates collected from patients from the south east Poland. Distribution and relation between H. pylori genotypes and clinical outcomes, if derived from the different geographic regions may differ widely, then it is important to determine the most prevalent genotypes in a specific region [22].

An important application of standard PCR is the detection of specific pathogenic factors of H. pylori. There are two main pathogenic segments: the cagPAI and the polymorphism of the vacA gene. Other genes coding molecules associated with induction of inflammation (dupA,iceA) can also be detected by PCR. It was reported that cagPAI do cause more severe peptic ulceration, extra digestive diseases, and is associated with development of precancerous lesions and gastric adenocarcinoma [19]. In our study, in $56 \%$ of $H$. pylori positive samples cagA gene were found that was comparable to the other Polish studies [23,24], and logistic regression revealed relationship between cag $A$ gene and clinical outcome. It was a risk factor positively associated with peptic ulcer diagnosis but negative association existed with GERD. Colonization with cagA-positive H. pylori strains was already shown to be inversely associated with reflux esophagitis and Barrett's esophagus [25]. 
H. pylori also produces a vacuolating cytotoxin, VacA, which has been associated with the more severe diseases, e.g., peptic ulcer disease and gastric adenocarcinoma [26,27]. The gene encoding this cytotoxin is present in all strains but exhibits a mosaicism in the terminal (s) and median (m) regions. There are several alleles corresponding to various amounts of toxin produced: $s 1 \mathrm{~m} 1$ corresponds to the highest production, followed by $s 1 m 2$, while strains with the $s 2 m 2$ allele do not produce any toxin. The vac $A$ genotypes (allelic variations) are significantly different in each country and previous studies have confirmed important geographic differences in these virulence factors [27-29]. Among different genotypes, infection with $H$. pylori strains containing vacA $\operatorname{sim} 1$ type was strongly associated with increased risk of gastric cancer or PUD [8,30,31]. In our study, most frequent allelic combination of vacA gene were $s 1 a m 2-38.7 \%$ and $s 2 m 2-32.3 \%$, that was similar to previous Polish studies $[23,24,32]$; however, statistically significant associations between vacAs1m1 type and GAST and PUD patients were observed ( $p=0.042$ and $p=0.038$, respectively). Our findings also shown that among cag $A$ positive strains, the combinations of $v a c A s 1 \mathrm{~m} 1 / \mathrm{cag} A+$ was the predominant pattern in GAST and PUD patients. When both cagA and vacA detection is performed, a strong association exists between the presence of $c a g A$ and $v a c A s 1$, corresponding to strains with the highest production of cytotoxin $[29,33]$ as well as more severe disease [34-36]. In our study, traditionally, less aggressive vacAs $2 m 2 c a g A(-)$ were most common in GERD patients (32\%).

Our laboratory findings suggest that gastric mucosa is colonized by mixed virulent type of $H$. pylori strains. In $8 \%$ of $H$. pylori positive samples mixed genotypes of $v a c A$ gene were detected, i.e., at least two different alleles of $m$ region. Mixed vacA genotypes were also observed in other studies suggesting high probability of colonization by a few different $H$. pylori strains $[28,29,33]$.

The role and correlation of H. pylori ice A (a gene induced by a contact with the gastric epithelium) in clinical outcomes is unclear. Our results revealed that $32.3 \%$ of $H$. pylori were harboring ice $A 1,35.5 \%$ were ice $A 2$, whereas $4.8 \%$ were mixed (iceA1/iceA2) which is consistent with other data from Poland but in younger population [24] and from Eastern Europe [37]. In other studies from European countries, it was shown that iceA1 allele was two times more frequent than iceA2 [15,38]. The iceA1 allele, encoding a CATG-specific restriction endonuclease, is regulated by the contact of $H$. pylori with the human gastric cells, has been suggested to be related to PUD $[15,16]$. However, like the other authors, we doubt these findings $[39,40]$. In our study, ice $A 1$ was negatively associated with gastritis whereas it was positively associated with GERD. Further research of $H$. pylori strains with different ice $A$ gene alleles could lead to clarifying its role in pathogenesis of human gastrodudenal diseases.

In our study, $35 \mathrm{H}$. pylori strains were tested; $51 \%$ of them were susceptible to all, and $49 \%$ were resistant to at least one of the tested antibiotics. Multiresistant strains accounted for as many as $23 \%$, and included those resistant to two (metronidazole and clarithromycin or metronidazole and rifampicin or metronidazole and levofloxacin) or three (metronidazole, clarithromycin, and levofloxacin) antibiotics. This study showed lower primary antibiotic resistance rate than those reported in other areas of Poland or Europe [41,42]. In Eastern and Central European countries, the prevalence of H. pylori strains resistant to metronidazole is higher than in other developed countries, reaching almost $50 \%$, and resistance to clarithromycin is as high as $30 \%$ and is still increasing, contributing to the failure of first-line therapy in approximately $70 \%$ of patients [32,41,42]. Such a high resistance to clarithromycin observed in Poland results mainly from excessive consumption of antibiotics, especially from the group of macrolides, and their widespread use in respiratory tract infections. Moreover, rates of resistance of H. pylori strains to levofloxacin have been very low in Poland [43], but the introduction of levofloxacin to eradication therapy of $H$. pylori infection quickly led to the emergence of resistant strains. Most of multi-resistant strains had genotype cagA(+) $(75 \%)$ and vacAs1 $(62.5 \%)$.

A major limitation of our work was relatively low number of patients with specific clinical manifestations. We had only nine patients with peptic ulcer and none with gastric cancer, which can only be explained by limited number of studied patients, considering the published reports regarding its incidence in Poland [44]. We had also a very low number of $H$. pylori culture findings that might be 
related to absence of microorganisms in the gastric biopsy specimens, loss of viability during transport, and antibiotic or IPP intake.

Another limitation was that we studied only a few virulence genes although other genes involved in adherence $(b a b A, s a b A)$ or in pathogenesis $(\operatorname{oip} A, \operatorname{dup} A)$ can be targeted to assess the virulence potential of $H$. pylori. To improve the significance of our study, especially the knowledge of populations from Eastern Europe, the importance of more recently disclosed vac $A$ and $\operatorname{cag} A$ genotypes-such as vac $A$ i-region/d-region and cag $A$ EPIYA-region-would be worthy of investigation.

\section{Conclusions}

This is the first study that reports the high prevalence and diversity of allelic combination of cagA, $v a c A$, and $i c a A$ genes in gastroduodenitis patients in southeast Poland. In our study, most frequent allelic combination of $v a c A$ gene were $s 1 \mathrm{~m} 2$ and $s 2 \mathrm{~m} 2$ and correlation between vacAs $1 \mathrm{~m} 1$ type and development of GAST and PUD in patients was shown. Our findings also noted a lower primary antibiotic resistance rate than those reported in other areas of Poland. However, new antimicrobial resistance studies should be conducted periodically and regionally in our country to provide information that may help to monitor effective eradication programs.

Author Contributions: Conceptualization, I.K.-G., A.M., and H.C.-L.; Methodology, I.K.-G. and S.A.; Formal analysis, I.K.-G.; Investigation, I.K.-G., R.S., and S.A.; Resources, H.C.-L., A.G., and P.M.; Writing-original draft preparation, I.K.-G., H.C.-L., R.S., and A.M.; Writing-review and editing, I.K.-G, H.C.-L., A.M., R.S., S.A., A.G., and P.M.; Supervision, H.C.-L. and A.M.; Funding acquisition, A.M. and H.C.-L.

Acknowledgments: The paper was developed using the equipment purchased within the agreement no. POPW.01.03.00-06-010/09-00 Operational Program Development of Eastern Poland 2007-2013, Priority Axis I, Modern Economy, Operations 1.3. Innovations Promotion.

Conflicts of Interest: The authors declare no conflict of interest. 


\section{Appendix A}

Table A1. Univariate analysis of factors associated with clinical diagnosis

\begin{tabular}{|c|c|c|c|c|c|c|c|c|c|c|c|c|}
\hline \multirow[b]{2}{*}{ Factor } & \multicolumn{4}{|c|}{ GAST } & \multicolumn{4}{|c|}{ PUD } & \multicolumn{4}{|c|}{ GERD } \\
\hline & $\begin{array}{l}\text { GAST }^{2} \\
(n=46)\end{array}$ & $\begin{array}{l}\text { Others } \\
(n=86)\end{array}$ & OR $(95 \% \mathrm{CI})$ & $p$ Value & $\begin{array}{l}\text { PUD }^{3} \\
(n=9)\end{array}$ & $\begin{array}{c}\text { Others } \\
(n=123)\end{array}$ & OR $(95 \% \mathrm{CI})$ & $p$-Value & $\begin{array}{l}\text { GERD }^{4} \\
(n=71)\end{array}$ & $\begin{array}{c}\text { Others } \\
(n=61)\end{array}$ & OR $(95 \% \mathrm{CI})$ & $p$-Value \\
\hline Age $($ mean $\pm S D)$ & $57.2 \pm 15.8$ & $57.4 \pm 15.7$ & $1.0(0.97-1.0)$ & 0.81 & $61.3 \pm 12.3$ & $57.1 \pm 15.8$ & $1.0(0.97-1.1)$ & 0.43 & $56.9 \pm 16.0$ & $57.9 \pm 15.3$ & $1.0(0.97-1.0)$ & 0.72 \\
\hline Male gender & $23(50.0)$ & $31(36.1)$ & $1.9(0.9-3.9)$ & 0.88 & $4(44.4)$ & $50(40.7)$ & $1.2(0.3-4.5)$ & 0.82 & $27(38.0)$ & $27(44.3)$ & $0.8(0.4-1.6)$ & 0.47 \\
\hline $\mathrm{BMI}^{1}($ mean $\pm \mathrm{SD})$ & $27.0 \pm 3.8$ & $25.8 \pm 3.4$ & $1.1(1.0-1.2)$ & 0.06 & $27.2 \pm 3.8$ & $26.1 \pm 3.6$ & $1.1(0.9-1.3)$ & 0.42 & $25.9 \pm 3.5$ & $26.6 \pm 3.8$ & $0.9(0.8-1.0)$ & 0.22 \\
\hline rural residence & $20(42.5)$ & $27(31.8)$ & $1.7(0.8-3.5)$ & 0.18 & $3(33.3)$ & 44 (35.8) & $1.1(0.2-4.7)$ & 0.92 & $24(33.8)$ & $23(38.3)$ & $0.8(0.4-1.7)$ & 0.59 \\
\hline Smoking & $12(26.1)$ & $28(32.9)$ & $0.7(0.3-1.6)$ & 0.42 & $3(33.3)$ & $37(30.1)$ & $1.4(0.3-6.1)$ & 0.66 & $20(28.2)$ & $20(33.3)$ & $0.8(0.4-1.7)$ & 0.52 \\
\hline ureC & $27(58.7)$ & $35(40.7)$ & $1.9(0.9-4.0)$ & 0.075 & $6(66.7)$ & $56(45.5)$ & $2.4(0.6-10.0)$ & 0.23 & $31(43.7)$ & $31(50.8)$ & $0.8(0.4-1.5)$ & 0.41 \\
\hline $\operatorname{cag} A$ & $16(34.8)$ & $19(22.1)$ & $2.0(0.9-4.4)$ & 0.093 & $5(55.6)$ & $30(24.4)$ & $3.9(1.0-15.3)$ & 0.054 & $16(22.5)$ & $19(31.2)$ & $0.6(0.3-1.4)$ & 0.27 \\
\hline vacA s $1 m 2$ & $10(21.7)$ & $13(15.1)$ & $2.0(0.7-5.2)$ & 0.17 & $3(33.3)$ & $20(16.3)$ & $3.4(0.6-18.1)$ & 0.15 & $11(15.5)$ & $12(19.7)$ & $0.7(0.3-1.8)$ & 0.48 \\
\hline$v a c A s 1 m 1$ & $8(17.4)$ & $6(7.0)$ & $3.4(1.0-11.0)$ & 0.042 & $3(33.3)$ & $11(8.9)$ & $6.2(1.1-34.6)$ & 0.038 & $5(7.0)$ & $9(14.8)$ & $0.4(0.1-1.4)$ & 0.17 \\
\hline$v a c A s 2 m 2$ & $7(15.2)$ & $13(15.2)$ & $1.4(0.5-3.9)$ & 0.56 & $0(0)$ & $20(16.3)$ & - & - & $12(16.9)$ & $8(13.1)$ & $1.2(0.4-3.2)$ & 0.77 \\
\hline iceA1 & $7(15.2)$ & $16(18.6)$ & $0.8(0.3-2.1)$ & 0.63 & $3(33.3)$ & $20(16.3)$ & $2.6(0.6-11.1)$ & 0.21 & $16(22.5)$ & $7(11.5)$ & $2.2(0.9-5.9)$ & 0.1 \\
\hline iceA2 & $11(23.9)$ & $14(16.3)$ & $1.6(0.7-3.9)$ & 0.29 & $3(33.3)$ & $22(17.9)$ & $2.3(0.5-9.8)$ & 0.26 & $10(14.1)$ & $15(24.6)$ & $0.5(0.2-1.2)$ & 0.13 \\
\hline
\end{tabular}

${ }^{1}$ BMI—body mass index; ${ }^{2}$ GAST—gastritis/duodenitis; ${ }^{3}$ PUD—peptic ulcer disease (gastric/duodenal); ${ }^{4}$ GERD—gastroesophageal reflux disease. 


\section{References}

1. Atherton, J.C. The pathogenesis of Helicobacter pylori-induced gastro-duodenal disease. Annu. Rev. Pathol. 2006, 1, 63-96. [CrossRef] [PubMed]

2. Eusebi, L.H.; Zagari, R.M.; Bazzoli, F. Epidemiology of Helicobacter pylori infection. Helicobacter 2014, 19, 1-5. [CrossRef]

3. Malfertheiner, P.; Megraud, F.; O’Morain, C.A.; Gisbert, J.P.; Kuipers, E.J.; Axon, A.T.; Bazzoli, F.; Gasbarrini, A.; Atherton, J.; Graham, D.Y.; et al. Management of Helicobacter pylori infection-The Maastricht V/Florence consensus report. Gut 2017, 66, 646-664. [CrossRef] [PubMed]

4. Makola, D.; Petura, D.A.; Crowe, S.E. Helicobacter pylori infection and related gastrointestinal diseases. J. Clin. Gastroenterol. 2007, 41, 548-558. [CrossRef] [PubMed]

5. Wen, S.; Moss, S.F. Helicobacter pylori virulence factors in gastric carcinogenesis. Cancer Lett. 2009, $282,1-8$. [CrossRef] [PubMed]

6. Covacci, A.; Censini, S.; Bugnoli, M.; Petracca, R.; Burroni, D.; Macchia, G.; Massone, A.; Papini, E.; Xiang, Z.; Figura, N. Molecular characterization of the 128-kDa immunodominant antigen of Helicobacter pylori associated with cytotoxicity and duodenal ulcer. Proc. Natl. Acad. Sci. USA 1993, 90, 5791-5795. [CrossRef]

7. Cover, T.L.; Blaser, M.J. Purification and characterization of the vacuolating toxin from Helicobacter pylori. J. Biol. Chem. 1992, 267, 10570-10575. [PubMed]

8. Atherton, J.C.; Cao, P.; Peek, R.M.; Tummuru, M.K.; Blaser, M.J.; Cover, T.L. Mosaicism in vacuolating cytotoxin alleles of Helicobacter pylori. Association of specific vacA types with cytotoxin production and peptic ulceration. J. Biol. Chem. 1995, 270, 17771-17777. [CrossRef]

9. Yamaoka, Y.; Graham, D.Y. Helicobacter pylori virulence and cancer pathogenesis. Future Oncol. 2014, 10, 1487-1500. [CrossRef]

10. Lage, A.P.; Godfroid, E.; Fauconnier, A.; Burette, A.; Butzler, J.P.; Bollen, A.; Glupczynski, Y. Diagnosis of Helicobacter pylori infection by PCR: Comparison with other invasive techniques and detection of cagA gene in gastric biopsy specimens. J. Clin. Microbiol. 1995, 33, 2752-2756.

11. Smith, S.M.; O’Morain, C.; McNamara, D. Antimicrobial susceptibility testing for Helicobacter pylori in times of increasing antibiotic resistance. World J. Gastroenterol. 2014, 20, 9912-9921. [CrossRef] [PubMed]

12. Bartnik, W.; Celińska-Cedro, D.; Dzieniszewski, J.; Laszewicz, W.; Mach, T.; Przytulski, K.; Skrzydlo-Radomanska, B. Guidelines from the polish society of gastroenterology for the diagnosis and treatment of Helicobacter pylori infection. Gastroenterol. Klin. 2014, 2, 41-49.

13. Patel, S.K.; Pratap, C.B.; Jain, A.K.; Gulati, A.K.; Nath, G. Diagnosis of Helicobacter pylori: What should be the gold standard? World J. Gastroenterol. 2014, 20, 12847-12859. [CrossRef] [PubMed]

14. Espinosa, M.G.C.; Vazquez, R.G.; Mendez, I.M.; Vargas, C.R.; Cerezo, S.G. Detection of the glmM gene in Helicobacter pylori isolates with novel primer by PCR. J. Clin. Microbiol. 2011, 49, 1650-1652. [CrossRef] [PubMed]

15. Van Doorn, L.; Figueiredo, C.; Sanna, R.; Plaisier, A.; Schneeberger, P.; De Boer, W.; Quint, W. Clinical relevance of the cagA, vacA, and iceA status of Helicobacter pylori. Gastroenterology 1998, 115, 58-66. [CrossRef]

16. Peek, R.M., Jr.; Thompson, S.A.; Donahue, J.P.; Tham, T.K.; Atherton, J.C.; Blaser, M.J.; Miller, G.G. Adherence to gastric epithelial cells induces expression of a Helicobacter pylori gene, iceA, that is associated with clinical outcome. Proc. Assoc. Am. Physicians 1998, 110, 531-544. [PubMed]

17. Grove, D.I.; Koutsouridis, G.; Cummins, A.G. Comparison of culture, histopatology and urease testing for diagnosis of Helicobacter pylori gastritis and susceptibility to amoxicillin, clarithromycin, metronidazole and tetracycline. Pathology 1998, 30, 183-187. [CrossRef] [PubMed]

18. Loffeld, R.J.; Stobbering, E.; Flendrig, J.A.; Arends, J.W. Helicobacter pylori in gastric biopsy specimens. Comparison of culture, modified giemsa stain, and immunohistochemistry. A retrospective study. J. Pathol. 1991, 165, 69-73. [CrossRef]

19. Mégraud, F.; Lehours, P. Helicobacter pylori detection and antimicrobial susceptibility testing. Clin. Microbiol. Rev. 2007, 20, 280-322. [CrossRef]

20. Duś, I.; Dobosz, T.; Manzin, A.; Loi, G.; Serra, C.; Radwan-Oczko, M. Role of PCR in Helicobacter pylori diagnostics and research-New approaches for study of coccoid and spiral forms of bacteria. Postepy Hig. Med. Dosw. (Online) 2013, 67, 261-268. [CrossRef] 
21. Correa, P.; Piazuelo, M.B. The gastric precancerous cascade. J. Dig. Dis. 2012, 13, 2-9. [CrossRef] [PubMed]

22. Módena, J.L.P.; Sales, A.I.L.; Acrani, G.O.; Russo, R.; Ribeiro, M.A.V.; Fukuhara, Y.; Da Silveira, W.D.; De Oliveira, R.B.; Brocchi, M. Association between Helicobacter pylori genotypes and gastric disorders in relation to the cag pathogenicity island. Diagn. Microbiol. Infect. Dis. 2007, 59, 7-16. [CrossRef] [PubMed]

23. Zalewska-Ziob, M.; Wiczkowski, A.; Strzelczyk, J.K.; Adamek, B.; Gawron, K.; Trapp, G.; Sieron, A.; Gadowska-Cicha, A. The prevalence of Helicobacter pylori vacA alleles in patients with chronic gastritis. Adv. Clin. Exp. Med. 2007, 16, 29-33.

24. Biernat, M.M.; Gościniak, G.; Iwańczak, B. Prevalence of Helicobacter pylori cagA, vacA, iceA, babA2 genotypes in Polish children and adolescents with gastroduodenal disease. Postepy Hig. Med. Dośw. 2014, 68, 1015-1021. [CrossRef] [PubMed]

25. Loffeld, R.J.; Werdmuller, B.F.; Kuster, J.G.; Perez-Perez, G.I.; Blaser, M.J.; Kuipers, E.J. Colonization with cagA-positive Helicobacter pylori strains inversely associated with reflux esophagitis and Barrett's esophagus. Digestion 2000, 62, 95-99. [CrossRef] [PubMed]

26. Figura, N.; Guglielmetti, P.; Rossolini, A.; Barberi, A.; Cusi, G.; A Musmanno, R.; Russi, M.; Quaranta, S. Cytotoxin production by Campylobacter pylori strains isolated from patients with peptic ulcers and from patients with chronic gastritis only. J. Clin. Microbiol. 1989, 27, 225-226.

27. Miehlke, S.; Kirsch, C.; Agha-Amiri, K.; Günther, T.; Lehn, N.; Malfertheiner, P.; Stolte, M.; Ehninger, G.; Bayerdörffer, E. The Helicobacter pylori vacA s1, $\mathrm{m} 1$ genotype and cagA is associated with gastric carcinoma in Germany. Int. J. Cancer 2000, 87, 322-327. [CrossRef]

28. Latifi-Navid, S.; Mohammadi, S.; Maleki, P.; Zahri, S.; Yazdanbod, A.; Siavoshi, F.; Massarrat, S. Helicobacter pylori vacA d1/-i1 genotypes and geographic differentiation between high and low incidence areas of gastric cancer in Iran. Arch. Iran. Med. 2013, 16, 330-337.

29. Van Doorn, L.; Figueiredo, C.; Mégraud, F.; Peña, S.; Midolo, P.; Queiroz, D.M.D.M.; Carneiro, F.; VanderBorght, B.; Pegado, M.D.G.F.; Sanna, R.; et al. Geographic distribution of vacA allelic types of Helicobacter pylori. Gastroenterology 1999, 116, 823-830. [CrossRef]

30. Fernández-Reyes, M.; Tamayo, E.; Rojas-Rengifo, D.; Fischer, W.; Carrasco-García, E.; Alonso, M.; Lizasoain, J.; Bujanda, L.; Cosme, Á.; Montes, M. Helicobacter pylori and primary antimicrobial resistance in Northern Spain. Eur. J. Clin. Investig. 2019, 13150. [CrossRef]

31. Idowu, A.; Mzukwa, A.; Harrison, U.; Palamides, P.; Haas, R.; Mbao, M.; Mamdoo, R.; Bolon, J.; Jolaiya, T.; Smith, S.; et al. Detection of Helicobacter pylori and its virulence genes (cagA, dupA, and vacA) among patients with gastroduodenal diseases in Chris Hani Baragwanath Academic Hospital, South Africa. BMC Gastroenterol. 2019, 19, 73. [CrossRef] [PubMed]

32. Iwańczak, B.W.; Laszewicz, F.; Iwańczak, K.; Dzierzanowska-Fangrat, K.; Rozynek, M.; Dzierzanowska, D.; Gosciniak, G.; Dlugosz, J.; Task force of The Polish Society of Gastroenterology. Genotypic and clinical differences of seropositive Helicobacter pylori children and adults in the Polish population. J. Physiol. Pharmacol. 2014, 65, 801-807.

33. Audibert, C.; Janvier, B.; Grignon, B.; Salaüna, L.; Burucoa, C.; Lecron, J.-C.; Fauchere, J.-L. Correlation between IL-8 induction, cagA status and vacA genotypes in 153 French Helicobacter pylori isolates. Res. Microbiol. 2000, 151, 191-200. [CrossRef]

34. Molina-Castro, S.; Garita-Combronero, J.; Malespin-Bendana, W.; Une, C.; Ramirez, V. Virulence factor genotyping of Helicobacter pylori isolated from Costa Rican dyspeptic patients. Microb. Pathogen. 2019, 128, 276-280. [CrossRef] [PubMed]

35. Matsunari, O.; Miftahussurur, M.; Shiota, S.; Suzuki, R.; Vilaichone, R.-K.; Uchida, T.; Ratanachu-Ek, T.; Tshering, L.; Mahachai, V.; Yamaoka, Y. Rare Helicobacter pylori virulence genotypes in Bhutan. Sci. Rep. 2016, 6, 22584. [CrossRef] [PubMed]

36. Akeel, M.; Shehata, A.; Elhafey, A.; Elmakki, E.; Aboshouk, T.; Ageely, H.; Mahfouz, M. Helicobacter pylori vacA, cagA and iceA genotypes in dyspeptic patients from southwestern region, Saudi Arabia: Distribution and association with clinical outcomes and histopathological changes. BMC Gastroenterol. 2019, $19,16$. [CrossRef]

37. Boyanova, L.; Yordanov, D.; Gergova, G.; Markowska, R.; Mitov, I. Association of iceA and babA genotypes in Helicobacter pylori strains with patient and strain characteristics. Antonie van Leeuwenhoek 2010, 98, 343-350. [CrossRef] 
38. Homan, M.; Luzar, B.; Kocjan, B.J.; Orel, R.; Močilnik, T.; Shrestha, M.; Kveder, M.; Poljak, M. Prevalence and clinical relevance of cagA, vacA, and iceA genotypes of Helicobacter pylori isolated from Slovenian children. J. Pediatr. Gastroenterol. Nutr. 2009, 49, 289-296. [CrossRef]

39. Lin, H.-J.; Perng, C.-L.; Lo, W.-C.; Wu, C.-W.; Tseng, G.-Y.; Li, A.F.-Y.; Sun, I.-C.; Ou, Y.-H.; Lin, C.-L.P.H.-J. Helicobacter pylori cagA, iceA and vacA genotypes in patients with gastric cancer in Taiwan. World J. Gastroenterol. 2004, 10, 2493-2497. [CrossRef]

40. Almeida, N.; Donato, M.M.; Romaozinho, J.M.; Luxo, C.; Cardoso, O.; Cipriano, M.A.; Marinho, C.; Fernandes, A.; Sofia, C. Correlation of Helicobacter pylori genotypes with gastric histopathology in the central region of a south-european country. Dig. Dis. Sci. 2015, 60, 74-85. [CrossRef]

41. Mégraud, F. Time to change approaches to Helicobacter pylori management. Lancet Gastroenterol. Hepatol. 2017, 2, 692-693. [CrossRef]

42. Bińkowska, A.; Biernat, M.M.; Łaczmański, Ł.; Gościniak, G. Molecular patterns of resistance among Helicobacter pylori strains in south-western Poland. Front. Microbiol. 2018, 9, 3154. [CrossRef] [PubMed]

43. Karczewska, E.; Klesiewicz, K.; Wojtas-Bonior, I.; Skiba, I.; Sito, E.; Czajecki, K.; Zwolińska-Wcisło, M.; Budak, A. Levofloxacin resistance of Helicobacter pylori strains isolated from patients in Southern Poland, between 2006-2012. Acta Pol. Pharm. 2014, 71, 477-483. [PubMed]

44. GLOBOCAN 2018. Available online: https://gco.iarc.fr (accessed on 6 July 2019).

(C) 2019 by the authors. Licensee MDPI, Basel, Switzerland. This article is an open access article distributed under the terms and conditions of the Creative Commons Attribution (CC BY) license (http://creativecommons.org/licenses/by/4.0/). 